\title{
Mercury Concentration Profile in Sediment Cores of a Tropical Lagoon under High Anthropogenic Activities around an Urban City-Abidjan, Côte d'Ivoire
}

\author{
Achille Gueu ${ }^{1,2^{*}}$, Sébastien Koffi Ouffoué ${ }^{2,3}$, Bruno Zeli Digbéhi ${ }^{1}$ \\ ${ }^{1}$ Laboratoire de géologie marine, Université Félix Houphouët BOIGNY, Abidjan, Côte d'Ivoire \\ ${ }^{2}$ Centre Ivoirien Antipollution, Abidjan, Côte d'Ivoire \\ ${ }^{3}$ Laboratoire de chimie organique et de substances naturelles, Université Félix Houphouët BOIGNY, Abidjan, Côte d'Ivoire \\ Email: *gueuachille7@gmail.com
}

How to cite this paper: Gueu, A., Ouffoué, S. K., \& Digbéhi, B. Z. (2021). Mercury Concentration Profile in Sediment Cores of a Tropical Lagoon under High Anthropogenic Activities around an Urban CityAbidjan, Côte d'Ivoire. Journal of Geoscience and Environment Protection, 9, 8394.

https://doi.org/10.4236/gep.2021.95007

Received: March 8, 2021

Accepted: May 25, 2021

Published: May 28, 2021

Copyright $\odot 2021$ by author(s) and Scientific Research Publishing Inc. This work is licensed under the Creative Commons Attribution International License (CC BY 4.0).

http://creativecommons.org/licenses/by/4.0/ (c) (i) Open Access

\begin{abstract}
The present study focuses on the quantification of mercury in sediment cores from Cocody, Banco, Koumassi and Milliardaires bays in Abidjan, Côte d'Ivoire. It aims at assessing the state of mercury contamination of the lagoon bottom using DMA-80 (Direct Mercury Analyser). The automatic analyzer DMA-80 mercury is an innovative instrument for the analysis of mercury at very low content in solid and liquid samples in five minutes, without requiring any prior steps of pretreatment wet. The results showed, according to the lithological description of different bays, that the cored sediments consist of mud, sand, sandy mud or muddy sand with occasional shells. In addition, our results showed the presence of mercury in the sediments of the lagoon bottom at a degree of contamination that varies from moderate to very high according to the calculated contamination factor $(\mathrm{CF})$ values. The highest contamination was observed in Cocody Bay at the surface with a contamination factor of 7.5, while the lowest contamination was observed in Milliardaires Bay at the water-sediment interface with a contamination factor of 1.67. In addition, mercury concentrations compared to sediment guide values (SQGs) reveal that these sediments mostly show occasional biological effects but no toxicity except Koumassi core (sediments at $20 \mathrm{~cm}$ depth). Also, dredging, hydrodynamics have probably impacted the mercury content. The depositional environment of mercury metal is therefore a limiting factor for its fate in the aquatic environment.
\end{abstract}


Keywords

DMA-80, Mercury, Pollution, Sediments

\section{Introduction}

Aquatic ecosystems cover $70 \%$ of the planet's surface. At the origin of life on earth, they are now threatened by pollution brought by human activities, in particular by urbanization and industrialization (Said et al., 2013). These pollutants therefore interfere with chemical and biological processes in the water column and sediments. Among the many compounds emitted by human activities, trace metal elements (TMEs) are one of the major sources of contamination. These TMEs enter aquatic systems through point sources (industrial and urban effluents) and diffuse (runoff, dry and wet atmospheric deposition) sources in particulate, dissolved and colloidal forms (Kennish, 2002). They can cause adverse effects on aquatic life and are transmitted to humans through the consumption of contaminated fish products that cause serious health impairment (Ndome et al., 2010; Said et al., 2013). Due to their toxicity and accumulation in aquatic environment, the determination of trace element concentrations is the subject of particular attention in several countries around the world (Kargin et al., 2001; Hashmi et al., 2002; Okocha \& Adedeji, 2011; Meshram et al., 2014). Nowadays, many countries including Côte d'Ivoire still practice activities providing trace metal elements including mercury to the environment, especially anthropogenic activities, which mainly feed aquatic environment, which discharge huge quantities of mercury into the rivers flowing towards the Ebrié lagoon (South of Abidjan) which is however very strategic for the Ivorian economic capital and even for the country (Côte d'Ivoire).

This lagoon body of water is used for many socio-economic needs in the development of the city of Abidjan. Unfortunately, it is the object of several aggressions due to the extent of industrial activities as well as agricultural and domestic activities. It thus presents itself as a receptacle for large quantities of liquid waste, very often without any primary treatment, and solid waste (Scheren et al., 2004; Kouassi, 2014). Several studies have been carried out on water, sediments and some fish species. Thus, mercury levels have been assessed in surface sediments of the Ebrié lagoon (Ahoussi et al., 2012; Traore et al., 2014; Traore et al., 2015; Wango et al., 2015; Coulibaly et al., 2018).

This study aims to assess the mercury content in $50 \mathrm{~cm}$ cores collected in four bays (Cocody and Banco in the north and Koumassi and Milliardaires in the south) of the large Ebrié Lagoon fault.

\section{Material and Method}

\subsection{Study Area}

The cores studied were taken from Cocody, Banco, Koumassi and Milliardaires 
Bay belonging to the Ebrié lagoon network (Figure 1).

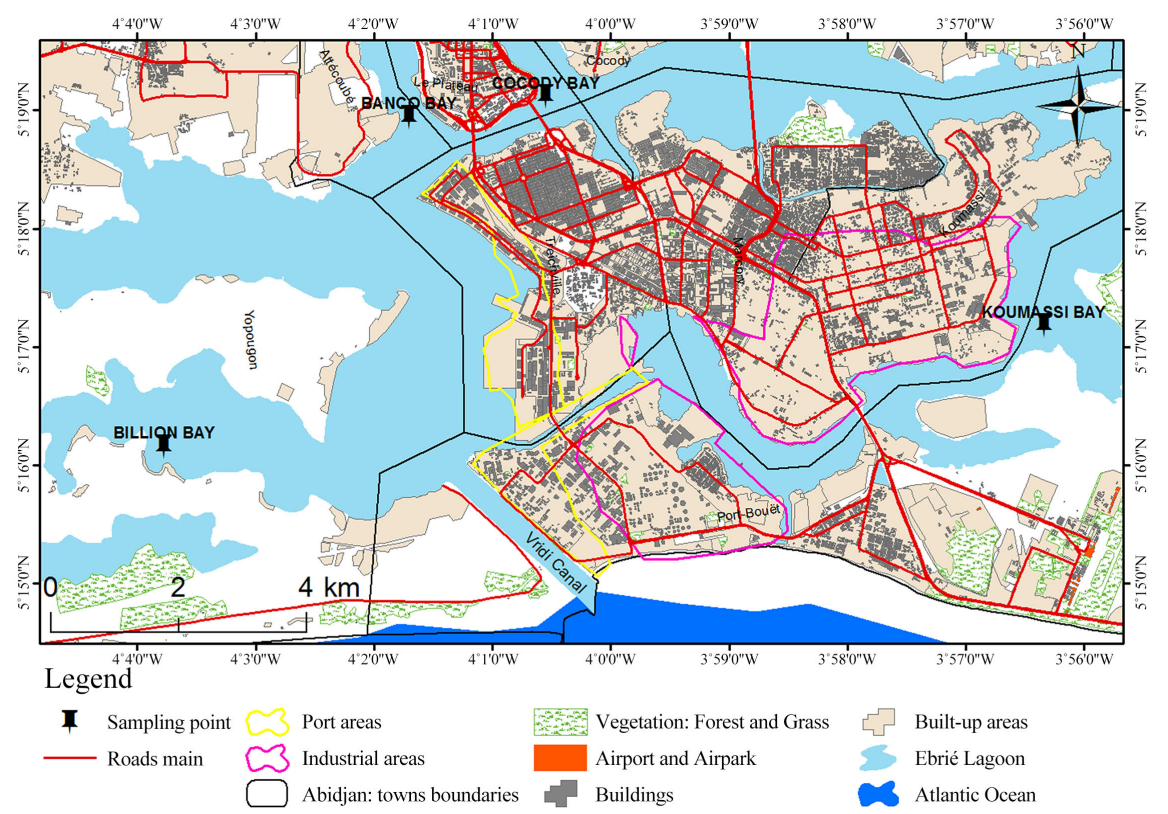

Figure 1. Location of the study area and core sampling points in the Ebrié lagoon system.

\subsection{Analysis Apparatus}

DMA whose operation is described in Figure 2, is an innovative instrument which is able to analyse the Mercury at very low levels in solid and liquid and gaz samples in six minutes, without need of pretreatment steps. It was built by Milestone it functions as an AAS (Atomic Absorption Spectrophotometer).

The DMA-80 analysis system (Figure 2) consists of a pneumatic arm, a rotating disc with 40 boat sites, a catalyst tube, an amalgamator, a light source (two mercury lamps), a constituted analyzer and 3 cells.

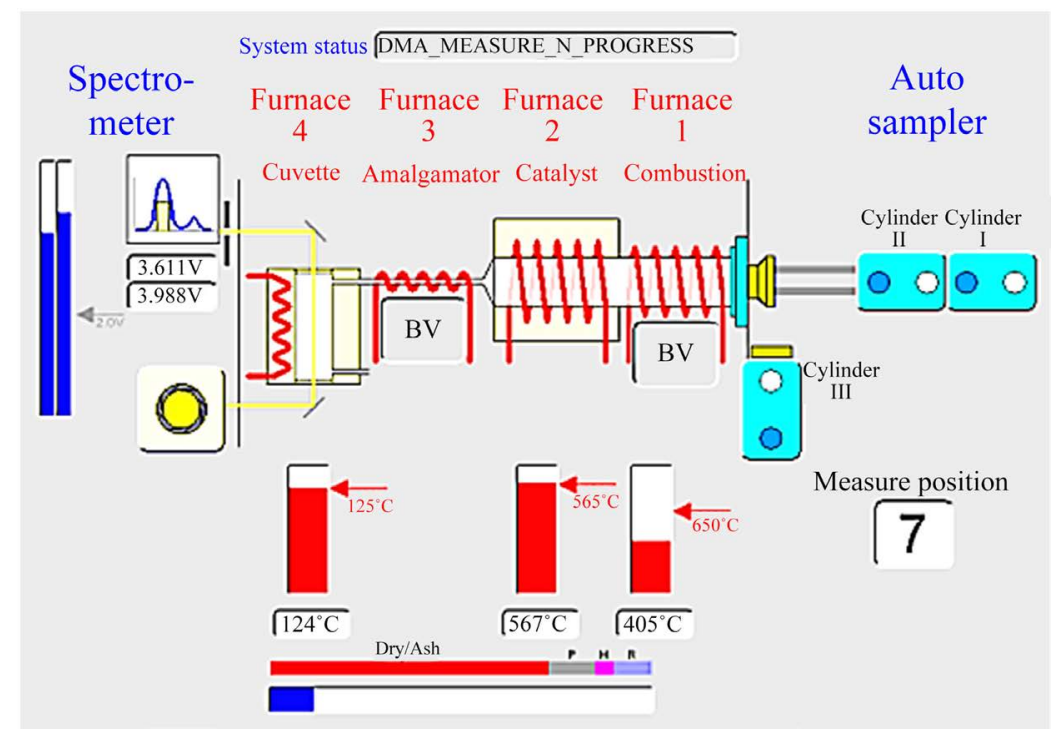

Figure 2. Operation of DMA. 


\subsection{Sampling and Materials}

Sampling points were chosen in the deepest areas of the bays to ensure perfect stratification stability of the sediment core. From a boat positioned vertically to the sampling point, a plunger make carries out a manual coring and extracts a core of at least $50 \mathrm{~cm}$.

The core, carefully taken with a coring machine, is brought to the surface of the water to be photographed, described and stored in PVC cases.

A summary log is established and will be completed afterwards by laboratory analysis of samples taken each 5 centimetres. Along this lithological log, it will be possible to follow the evolution of the mercury in relation to the variations in facies.

\subsection{Method of Analysis and Apparatus}

In the laboratory, sediment samples are dried in an oven at room temperature. The dried sediment are then crushed in a mortar and sieved with a $63 \mu \mathrm{m} \mathrm{di-}$ ameter sieve to make it homogeneous in order to facilitate atomization. Thus a mass of the fraction of $\Phi<63 \mu \mathrm{m}$ is collected for analysis at DMA 80 for mercury evaluation and covering three tests each.

The samples are introduced into the DMA- 80 mercury analyzer by the integrated autosampler. Prior to combustion, the sample is initially dried in an oxygen flow through a quartz tube located inside a resistance furnace. The sample is then thermally decomposed under oxygen. The combustion gases are then decomposed in a catalytic column at $650^{\circ} \mathrm{C}$, where halides and oxides are also trapped. This operating principle eliminates most matrix effects and allows the measurement of solid samples with calibration with liquid phase standards. The remaining decomposition products are then transported to the gold amalgamator which selectively traps the mercury. The continuous flow of oxygen removes any residual gases or decomposition products. The amalgamator is then rapidly heated, resorbing the mercury vapor to the measuring cells where the height of the absorbance peak is measured according to the mercury content. The measurement cycle takes less than five minutes per sample (Wedepohl, 1995).

\section{- Calculation of the contamination factor}

The calculation of the contamination factor was used to assess the level of mercury contamination in the sediments studied. The calculation of this factor uses the geochemical background and the values measured in the field (Coulibaly et al., 2010). This factor is calculated using the following formula:

$$
\mathrm{FC}=\mathrm{Cmetal} / \mathrm{C} \text { geochemical background of metal }
$$

Cmetal: Concentration of metal in the sediment

C geochemical background metal: Metal value of the geochemical background metal

A classification follows according to the variation of the FC values:

$\mathrm{FC}<1$ : low contamination.

$1 \leq \mathrm{FC}<3$ : moderate contamination. 
$3 \leq \mathrm{FC}<6$ : considerable contamination.

$\mathrm{FC} \geq 6$ : very high contamination.

\section{- Use of sediment guide values (SQGs)}

Many tools have been developed to determine whether metallic or organic contaminants associated with sediments can negatively affect aquatic organisms. Sediment Quality Guideline (SQG) values have thus been obtained from field data (chemical, ecological and toxicological indicators). Toxicity thresholds ERL (Effect Range Low) and ERM (Effect Range Medium) were defined (Long et al., 1995). These thresholds or toxicity criteria were obtained empirically, i.e. by compiling the results of numerous studies carried out either in the laboratory or in the natural environment and for which the level of sediment contamination and toxicity was available.

From this database, these authors defined for each contaminant the concentrations for which biological effects are rarely (below ERL), occasionally (between ERL and ERM) or frequently encountered (above ERM). In this way, the toxicity thresholds developed take into account the effects due to the mixture of contaminants as well as many characteristics of the sediment.

\section{Results}

\subsection{Lithology of Core Sediments}

Table 1 presents the results of the lithological analysis of the sediments from four bays in the study area.

Table 1. Lithological analysis of core sediments.

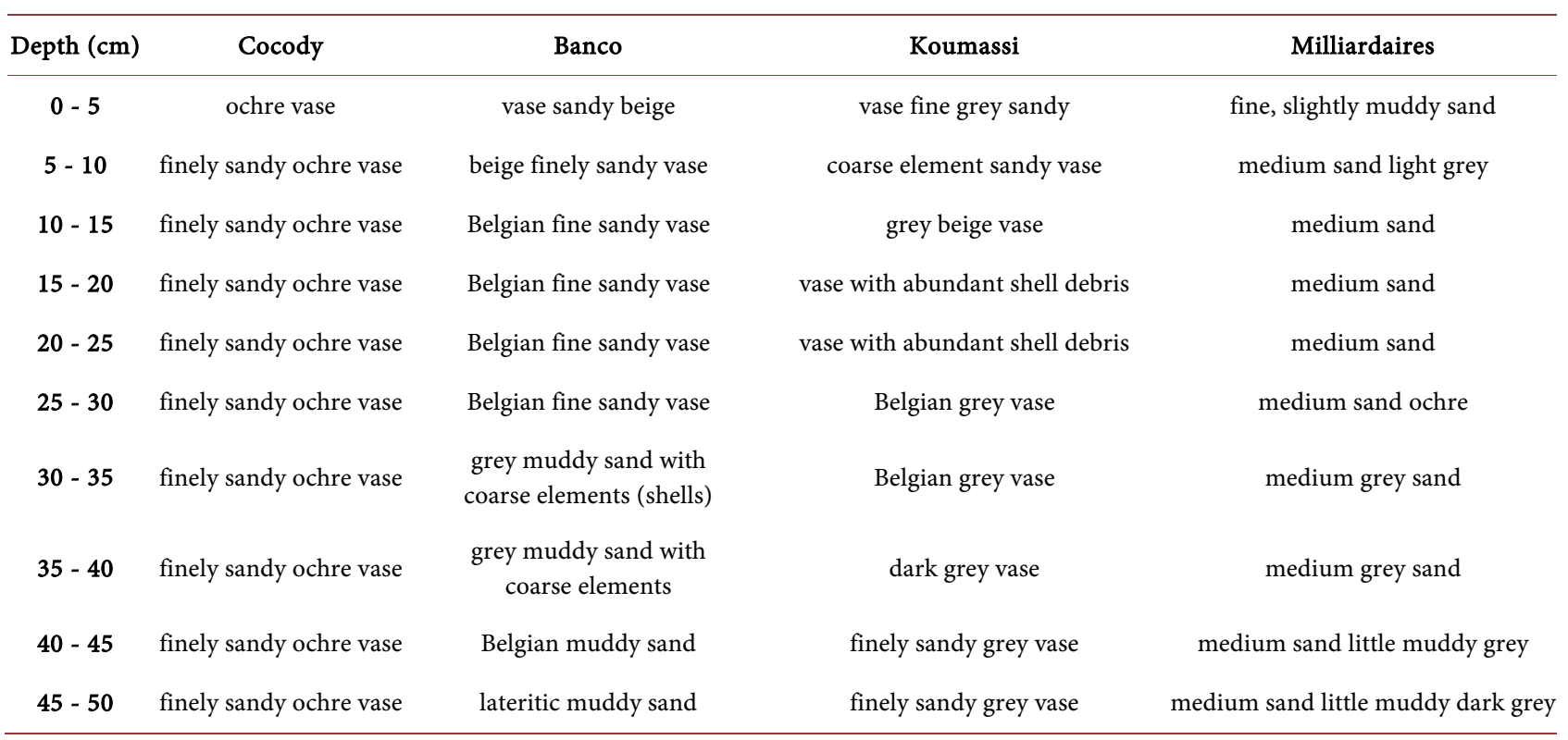

\subsection{Mercury Levels along Cores}

The different concentrations $(\mu \mathrm{g} / \mathrm{kg}$ ) of mercury in the four cores (Cocody, Banco, Koumassi and Milliardaires) studied are shown in Table 2. 
Table 2. Mercury concentrations ( $\mu \mathrm{g} / \mathrm{kg}$ ) along the cores in the study area.

\begin{tabular}{ccccccccc}
\hline Samples & Cocody & Std cocody & Banco & Std Banco & Koumassi & $\begin{array}{c}\text { Std } \\
\text { Koumassi }\end{array}$ & Milliardaires & $\begin{array}{c}\text { Std } \\
\text { Milliardaires }\end{array}$ \\
\hline Sp1 (0 - 5) & 394.8 & 2.25 & 273.16 & 1.18 & 288.99 & 3.17 & 112.63 & 8.98 \\
Sp2 (5 - 10) & 351.3 & 1.21 & 288.25 & 0.83 & 204.03 & 0.49 & 98.14 & 1.39 \\
Sp3 (10 - 15) & 394.3 & 9.89 & 304.05 & 0.91 & 308.22 & 0.60 & 92.10 & 0.52 \\
Sp4 (15 - 20) & 381.3 & 3.96 & 297.67 & 3.66 & 304.16 & 1.36 & 96.43 & 2.00 \\
Sp5 (20 - 25) & 279.0 & 5.09 & 354.30 & 2.51 & 728.05 & 13.99 & 115.56 & 1.32 \\
Sp6 (25 - 30) & 383.5 & 0.32 & 355.41 & 2.51 & 304.96 & 0.74 & 149.97 & 0.32 \\
Sp7 (30 - 35) & 350.5 & 1.41 & 271.88 & 4.06 & 316.13 & 1.57 & 95.61 & 4.20 \\
Sp8 (35 - 40) & 302.4 & 0.57 & 256.57 & 0.70 & 342.93 & 1.15 & 147.46 & 0.66 \\
Sp9 (40 - 45) & 366.6 & 2.25 & 209.97 & 3.92 & 319.98 & 1.92 & 244.41 & 116.19 \\
Sp10 (45 - 50) & 318.9 & 0.42 & 238.08 & 2.46 & 334.27 & 1.90 & & 0.24
\end{tabular}

\subsection{Fluctuation of Mercury from the Surface to the Bottom in the Different Bays}

Figures 3-6 below show the lithological profiles of the different bays in relation to the mercury content.

In Cocody Bay, the first 5 centimeters show us that the highest concentration of mercury is $394.8 \mu \mathrm{g} / \mathrm{kg}$. Indeed, mercury levels evolve regressively from pure ochre $(394.8 \mu \mathrm{g} / \mathrm{kg})$ to finely sandy $(273.0 \mu \mathrm{g} / \mathrm{kg})$ along the core (Figure 3$)$.

In Banco Bay, the highest concentration $(255.41 \mu \mathrm{g} / \mathrm{kg})$ is reached at $25 \mathrm{~cm}$ depth. Concentrations evolve in sandy mud to reach the maximum $(255.41 \mu \mathrm{g} / \mathrm{kg})$ at $25 \mathrm{~cm}$ depth in the same lithology. When the facies change, i.e. in muddy sands, this concentration will gradually drop to reach the value of $238.08 \mu \mathrm{g} / \mathrm{kg}$ at $45 \mathrm{~cm}$ depth (Figure 4).

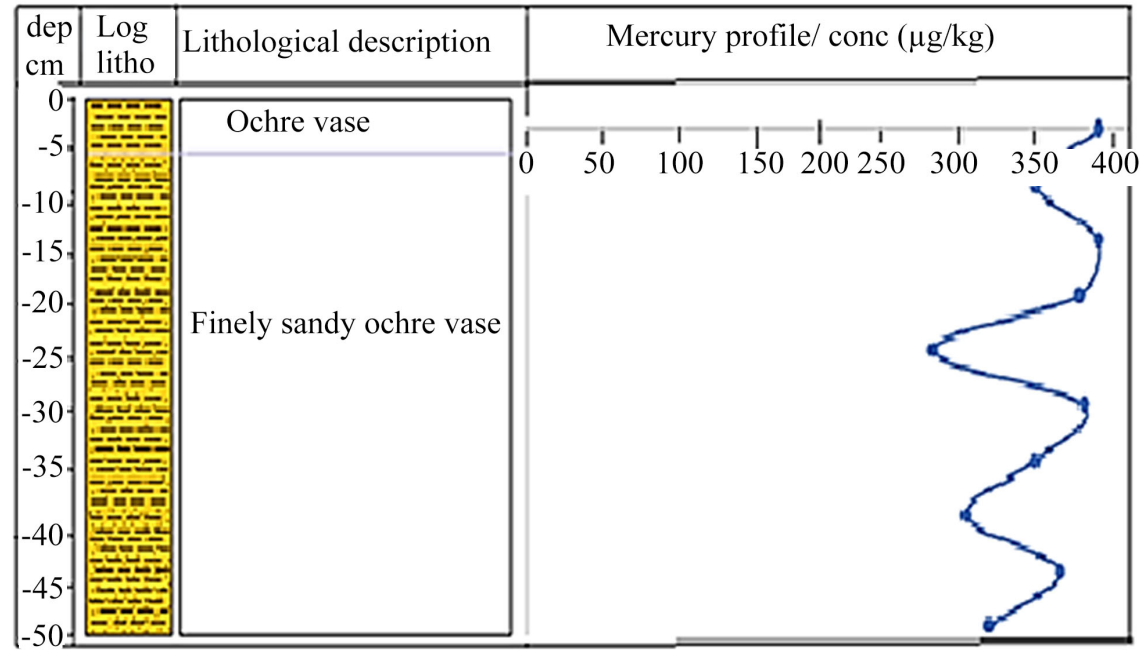

Figure 3. Evolution curve of the mercury concentration in the sediment according to the lithology along Cocody core. 


\begin{tabular}{|c|c|c|c|}
\hline $\begin{array}{l}\text { dep } \\
\mathrm{cm}\end{array}$ & $\begin{array}{l}\text { Log } \\
\text { litho }\end{array}$ & Lithological description & $\begin{array}{l}\text { Mercury profile } \\
\text { conc }(\mu \mathrm{g} / \mathrm{kg})\end{array}$ \\
\hline \multirow{4}{*}{\multicolumn{2}{|c|}{ 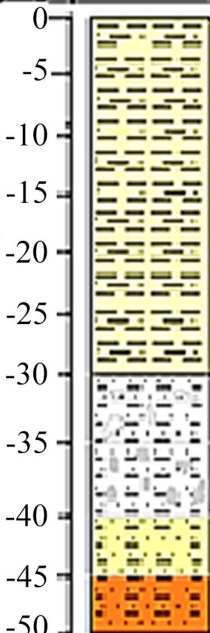 }} & Vase sandy beige & \multirow[t]{4}{*}{ 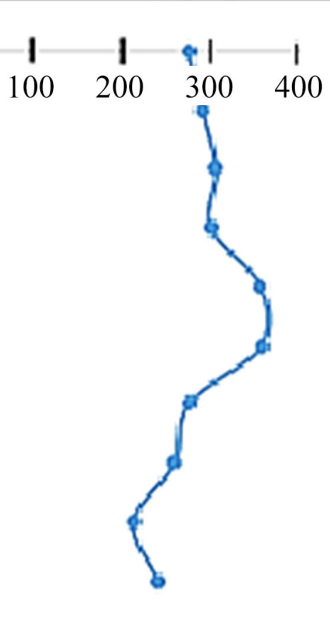 } \\
\hline & & $\begin{array}{l}\text { Grey muddy sand with } \\
\text { coarse element (shell) }\end{array}$ & \\
\hline & & $\begin{array}{l}\text { Grey muddy sand with coarse } \\
\text { elements }\end{array}$ & \\
\hline & & $\begin{array}{l}\text { Belgian muddy sand } \\
\text { Lateritic muddy sand }\end{array}$ & \\
\hline
\end{tabular}

Figure 4. Evolution curve of the mercury concentration in the sediment according to the lithology along Banco core.

At the Koumassi Bay, a large concentration peak $(728.5 \mu \mathrm{g} / \mathrm{kg})$ occurs at 20 $\mathrm{cm}$ depth (Figure 5). Indeed, the peak concentration observed on the mercury curve is found at $25 \mathrm{~cm}$ depth in the mud with abundant shell debris. The low concentration is located in sandy mud with coarse elements. In this core we can also see that the concentrations in the same lithologies are close to each other.

For Milliardaires Bay (Figure 6), mercury concentrations are relatively low. It has a core essentially made up of sand where the concentration evolves regularly and muddy sand which contains the highest concentration $(244.41 \mu \mathrm{g} / \mathrm{kg})$ of this core at $40 \mathrm{~cm}$ depth of.

\begin{tabular}{|c|l|l|llll|}
\hline $\begin{array}{l}\text { dep } \\
\mathrm{cm}\end{array}$ & $\begin{array}{l}\text { Log } \\
\text { litho }\end{array}$ & Lithological description & \multicolumn{4}{|c|}{$\begin{array}{c}\text { Mercury profile } \\
\text { conc }(\mu \mathrm{g} / \mathrm{kg})\end{array}$} \\
\hline 0 \\
-5 \\
10
\end{tabular}

Figure 5. Evolution curve of the mercury concentration in the sediment according to the lithology along Koumassi core. 


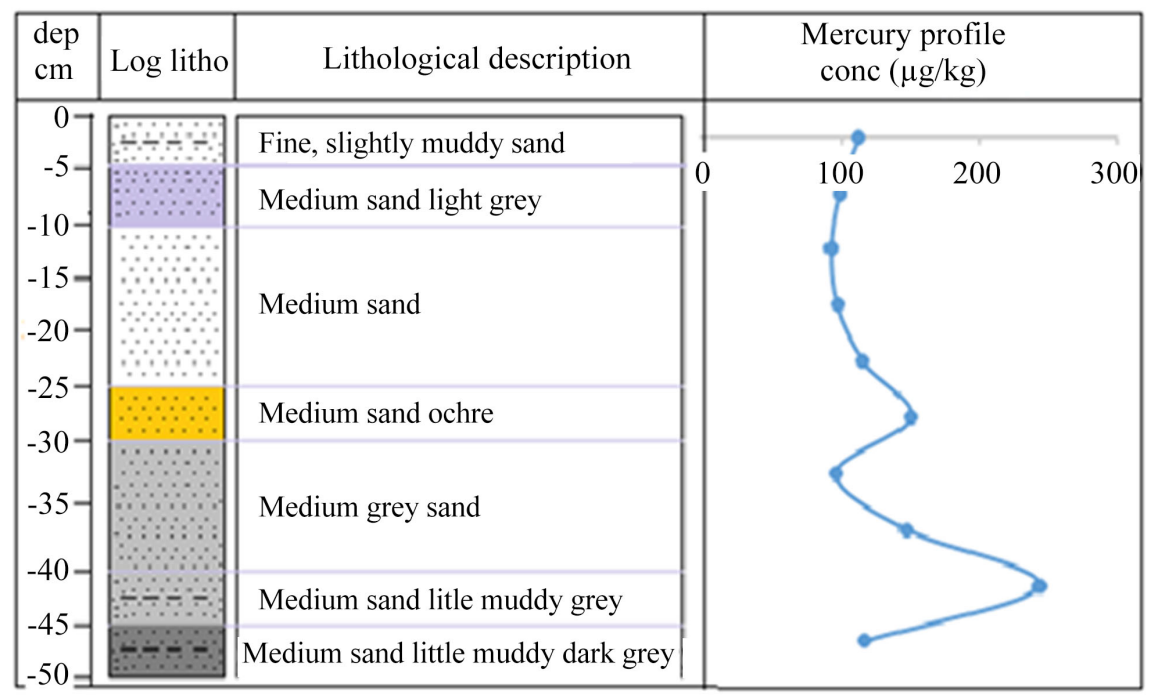

Figure 6. Evolution curve of the mercury concentration in the sediment according to the lithology along Milliardaires core.

\section{Contamination Factor (CF)}

Table 3 below shows the contamination factor values calculated in each sample and per core.

Table 3. Contamination factor values of the cores studied.

\begin{tabular}{ccccc}
\hline Samples & Cocody & Banco & Koumassi & Milliardaires \\
\hline Sp1 (0 - 5) & 7.5 & 4.88 & 5.16 & 2.01 \\
Sp2 (5 - 10) & 6.27 & 5.15 & 3.64 & 1.75 \\
Sp3 (10 - 15) & 7.04 & 5.43 & 5.50 & 1.64 \\
Sp4 (15 - 20) & 6.81 & 5.32 & 5.43 & 1.72 \\
Sp5 (20 - 25) & 4.98 & 6.33 & 13.00 & 2.06 \\
Sp6 (25 - 30) & 6.85 & 6.35 & 5.44 & 2.68 \\
Sp7 (30 - 35) & 6.26 & 4.86 & 5.64 & 1.71 \\
Sp8 (35 - 40) & 5.4 & 4.58 & 6.12 & 2.63 \\
Sp9 (40 - 45) & 6.55 & 3.75 & 5.71 & 4.36 \\
Sp10 (45 - 50) & 5.69 & 4.25 & 5.97 & 2.07 \\
\hline
\end{tabular}

Results show considerable sediment contamination in cores from Cocody, Banco and Koumassi bays at the water-sediment interface at $15 \mathrm{~cm}$ depth $(3 \leq$ $\mathrm{FC}<6)$. In addition, there is very high contamination $(\mathrm{FC}>6)$ at deep in these bays.

As for the core from the Bay of Milliardaires, the contamination is moderate at the water-sediment interface $(1 \leq \mathrm{FC}<3)$. However, at a depth of $40 \mathrm{~cm}$, there is considerable contamination of the sediment $(3 \leq \mathrm{FC}<6)$.

Sediment Guide Values (SQGs)

Table 4 presents the potential toxicity effect of Ebrié Lagoon sediments. This 
toxicity was assessed by comparing the mercury concentrations measured with the different sedimentary guide values. The sediment concentrations in the cores from Cocody, Banco and Koumassi bays are all between ERL and ERM attesting occasional biological effects.

However, in Koumassi Bay, at a depth of $20 \mathrm{~cm}$, the sediment concentration is higher than the ERM attesting to frequent biological effects.

As for the core taken in the Bay of Milliardaires, the sediment concentrations are mostly lower than the ERM, indicating that these sediments have biological effects that are rarely encountered. However, at a depth of $40 \mathrm{~cm}$, a concentration between the ERL and the ERM with biological effects occasionally encountered was noted.

Table 4. Comparison of measured concentrations with sediment guide values.

\begin{tabular}{|c|c|c|c|c|c|c|c|c|c|c|c|c|}
\hline \multirow[b]{2}{*}{ Samples } & \multicolumn{3}{|c|}{ Cocody } & \multicolumn{3}{|c|}{ Banco } & \multicolumn{3}{|c|}{ Koumassi } & \multicolumn{3}{|c|}{ Milliardaires } \\
\hline & Conc. & $\begin{array}{c}\text { ERL } \\
(150 \mu \mathrm{g} / \mathrm{kg})\end{array}$ & $\begin{array}{c}\text { ERM } \\
(710 \mu \mathrm{g} / \mathrm{kg})\end{array}$ & Conc & $\begin{array}{c}\text { ERL } \\
(150 \mu \mathrm{g} / \mathrm{kg})\end{array}$ & $\begin{array}{c}\text { ERM } \\
(710 \mu \mathrm{g} / \mathrm{kg})\end{array}$ & Conc & $\begin{array}{c}\text { ERL } \\
(150 \mu \mathrm{g} / \mathrm{kg}\end{array}$ & $\begin{array}{c}\text { ERM } \\
(710 \mu \mathrm{g} / \mathrm{kg})\end{array}$ & Conc. & $\begin{array}{c}\text { ERL } \\
(150 \mu \mathrm{g} / \mathrm{k}\end{array}$ & $\begin{array}{c}\text { ERM } \\
(710 \mu \mathrm{g} / \mathrm{kg})\end{array}$ \\
\hline Sp1 $(0-5)$ & 394.8 & $>$ & $<$ & 273.16 & $>$ & $<$ & 288.99 & $>$ & $<$ & 112.63 & $<$ & $<$ \\
\hline Sp2 $(5-10)$ & 351.3 & $>$ & $<$ & 288.25 & $>$ & $<$ & 204.03 & $>$ & $<$ & 98.14 & $<$ & $<$ \\
\hline Sp3 $(10-15)$ & 394.3 & $>$ & $<$ & 304.05 & $>$ & $<$ & 308.22 & $>$ & $<$ & 92.10 & $<$ & $<$ \\
\hline Sp4 (15 - 20) & 381.3 & $>$ & $<$ & 297.67 & $>$ & $<$ & 304.16 & $>$ & $<$ & 96.43 & $<$ & $<$ \\
\hline Sp5 (20 - 25) & 279.0 & $>$ & $<$ & 354.30 & $>$ & $<$ & 728.05 & $>$ & $>$ & 115.56 & $<$ & $<$ \\
\hline Sp6 $(25-30)$ & 383.5 & $>$ & $<$ & 355.41 & $>$ & $<$ & 304.96 & $>$ & $<$ & 149.97 & $<$ & $<$ \\
\hline Sp7 $(30-35)$ & 350.5 & $>$ & $<$ & 271.88 & $>$ & $<$ & 316.13 & $>$ & $<$ & 95.61 & $<$ & $<$ \\
\hline Sp8 $(35-40)$ & 302.4 & $>$ & $<$ & 256.57 & $>$ & $<$ & 342.93 & $>$ & $<$ & 147.46 & $<$ & $<$ \\
\hline Sp9 (40 - 45) & 366.6 & $>$ & $<$ & 209.97 & $>$ & $<$ & 319.98 & $>$ & $<$ & 244.41 & $>$ & $<$ \\
\hline Éch10 (45 - 50) & 318.9 & $>$ & $<$ & 238.08 & $>$ & $<$ & 334.27 & $>$ & $<$ & 116.19 & $<$ & $<$ \\
\hline
\end{tabular}

NB: >: Mercury concentration is higher than the guide value, <: Mercury concentration is below the guide value.

\section{Discussion}

Lithological analyses have shown that the cored sediments consist of mud, sand, sandy mud or muddy sand with occasional shells. These results are consistent with those of Tastet and Guiral (1994) whose analyses involved nearly 250 samples taken with the Shipeck skip over 20 cores $(100 \mathrm{~cm})$ in the Ebrié lagoon. Their study attests that the sediments of the lagoon bottoms are composed of sands with very variable granulometry (type 1), silts and clayey silts (type 3) and silts or clays (type 2). This abundance of silt could be explained by the feeding of the Ebrié lagoon system mainly by suspended matter from rivers and runoff on the shore. Soro et al. (2009) also showed the presence of mud, clays and coarse sands in the lagoon bottoms of the Ebrié lagoon. They were more interested in the surface sediments because their sampling was carried out with a shipeck skip, contrary to the present work and those of Tastet and Guiral (1994) who proceeded by coring. In addition, our results are similar to those of Traore et al. 
(2012) who found Quaternary sands and silts in the southern part of the Ivorian sedimentary basin on the eastern edge of the Aghien lagoon and along the Mé River. Also, the analysis of mercury concentrations in the sediments of different cores showed a variation in the values of these concentrations from one core to another and even within the same core which explains the fluctuation of the mercury curves. The large peak concentration $(728.5 \mu \mathrm{g} / \mathrm{kg})$ observed particularly at a depth of about $20 \mathrm{~cm}$ in Koumassi bay (Figure 5) can be explained by the lithology of the sediments at this level, made up of mud, but also by the presence of shells which are excellent fixatives metals in general and mercury in particular (Leblanc et al., 2006). Moreover, we can affirm that our results corroborate those of Marchand and Martin (1985) who showed that the highest mercury concentrations were found in Banco, Koumassi and Adjamé, which are at the heart of the city of Abidjan under strong anthropogenic pressure. Thus, the presence of mercury in the bottoms of the Ebrié lagoon at levels that have harmful effects on burrowing organisms corroborates the work of Touré and colleagues (Touré et al., 2018).

Concerning the values of the contamination factors, the results showed that all the sediments of the cores from the lagoon bottoms of our study area were contaminated with mercury. This contamination varies from one sediment to another, going from moderate to very high and even considerable. The detection of the contamination leads us to confirm the presence of the danger linked to mercury in the sediments. This presence is confirmed in the lagoon funds through several studies (Ahoussi et al., 2012; Traore et al., 2014; Traore et al., 2015; Wango et al., 2015; Coulibaly et al., 2018).

Finally, the analysis based on sediment guide values showed that the sediments of the lagoon bottoms studied in the present study have adverse biological effects on organisms. Indeed, Touré et al. (2018) based the characterization of their sediments from the Bay of Abou Abou (Ebrié lagoon) on the quality criteria TEC (threshold effect concentration) and PEC (probable effect concentration) other than the criteria used in the present study. The mercury levels in their study were all between the TEC and PEC, thus attesting that the sediments are not toxic but present possible harmful effects in accordance with the effects of sediment of this work on organisms.

\section{Conclusion}

Evaluation of the mercury concentration in the sediment cores of the lagoon bays of Abidjan studied indicates the presence of mercury in these sediments. The degree of contamination varies from moderate to very high. Mercury concentrations compared to sediment guide values reveal that these sediments mostly show occasional biological effects, but do not show toxicity, with the exception of the Koumassi core (sediments at $20 \mathrm{~cm}$ depth). The variation in mercury content in the sediments is irregular, probably related to the lithological heterogeneity of the sediments made up of mud and fine sands influencing mercury fixation. Also, dredging, hydrodynamics (high and low tide, river in- 
flow, runoff, etc.) have probably impacted the mercury content. The environment in which the mercury metal is deposited is therefore a limiting factor for its fate in the aquatic environment.

\section{Conflicts of Interest}

The authors declare no conflicts of interest regarding the publication of this paper.

\section{References}

Ahoussi, K. E., Koffi, Y. B., Loko, S., Kouassi, A. M., Soro, G., \& Biemi, J. (2012). Characterization of Metallic Trace Elements ( $\mathrm{Mn}, \mathrm{Ni}, \mathrm{Zn}, \mathrm{Cd}, \mathrm{Cu}, \mathrm{Pb}, \mathrm{Cr}, \mathrm{Co}, \mathrm{Hg}$, As) in Surface Waters of the Commune of Marcory, Abidjan Côte d'Ivoire: Case of the Village of Abia Koumassi. Geo-Eco-Trop, 36, 159-174.

Coulibaly, A. S., Monde, S., \& Aka, K. (2010). Bioavailability and Chemical Specifications of Metallic Trace Elements in a Confined Lagoon Environment. International Journal of Africana Studies, 4, 1-52.

Coulibaly, S., Atse, B. C., \& Koffi, K. M. (2018). Heavy Metal Contamination of the Water-Sediment and Muscle Matrix of Tilapia Oreochromis niloticus from Three Fish Farms in Côte d'Ivoire. African Agronomy, 30, 249-259.

Hashmi, M. I., Mustafa, S., \& Tariq, S. A. (2002). Heavy Metal Concentrations in Water and Tiger Prawn (Penaeus monodon) from Grow-Out Farms in Sabah, North Borneo. Food Chemistry, 79, 151-156. https://doi.org/10.1016/S0308-8146(02)00123-1

Kargin, F., Dönmez, A., \& Çoğun, H. Y. (2001). Distribution of Heavy Metals in Different Tissues of the Shrimp Penaeus semiculatus and Metapenaeus monocerus from the Iskenderun Gulf, Turkey: Seasonal Variations. Bulletin of Environmental Contamination and Toxicology, 66, 102-109. https://doi.org/10.1007/s0012800211

Kennish, M. J. (2002). Environmental Threats and Environmental Future of Estuaries. Environmental Conservation, 29, 78-107. https://doi.org/10.1017/S0376892902000061

Kouassi, N. L. B. (2014). Contribution to the Study of the Distribution, Mobility and Potential Toxicity of the Metals Copper, Zinc and Cadmium in the Sediments of a Tropical Estuary (Ebrié Lagoon, Côte d'Ivoire) (No. 880). Doctoral Thesis, Abidjan, Ivory Coast: Université Félix Houphouët-Boigny.

Leblanc, J.-C., Volatier, J.-L., Sirot, V., \& Nawel, B.-A. (2006). Study of Food Consumption of Seafood and Impregnation with Trace Elements, Pollutants and Omega 3 (CALIPSO), AFSSA, INRA, 127 p.

Long, E. R., Bin, C., Smith, S. L., \& Calder, F. D. (1995). Incidence of Adverse Biological Effects within Ranges of Chemical Concentrations in Marine and Estuarine Sediments. Environmental Management, 19, 8-97. https://doi.org/10.1007/BF02472006

Marchand, M., \& Martin, J. L. (1985). Determination of Chemical Pollution (Hydrocarbons, Organochlorines, Metals) in the lagoon of Abidjan (Ivory Coast) by Studying the Sediments. Tropical Oceanography, 20, 25-39.

Meshram, L. N., Udawant, S. M., Pawar, S., \& Mishra, P. S. (2014). Bioaccumulation of Heavy Metals $(\mathrm{Zn}, \mathrm{Pb}, \mathrm{Cd}$, and $\mathrm{Ni}$ ) in Tissues of Penaeus monodon (Fabricius, 1798) from India. International Journal of Advanced Research, 2, 548-555

Ndome, C. B., Ekaluo, U. B., \& Asuquo, F. E. (2010). Comparative Bioaccumulation of Heavy Metals ( $\mathrm{Fe}, \mathrm{Mn}, \mathrm{Zn}, \mathrm{Cu}, \mathrm{Cd}$ and $\mathrm{Cr}$ ) by Some Edible Aquatic Molluscs from the Atlantic Coastline of South Eastern Nigeria. Journal of Fish and Marine Sciences, 2, 317-321. 
Okocha, R. C., \& Adedeji, O. B. (2011). Heavy Metal Concentrations in Prawns (Macrobrachium vollenhovenii) and Water from Asejire River Southwestern Nigeria. Advances in Environmental Biology, 5, 1359-1363.

Said, M. I. M., Sabri, S., Azman, S., \& Muda, K. (2013). Arsenic, Cadmium and Copper in Gastropod Strombus canarium in Western Part of Johor Straits. World Applied Sciences Journal, 23, 734-739.

Scheren, P. A. G. M., Kroeze, C., Janssen, F. J. J. G., Hordijk, L., \& Ptasinski, K. J. (2004). Integrated Water Pollution Assessment of the Ebrié Lagoon, Ivory Coast, West Africa. Journal of Marine Systems, 44, 1-17. https://doi.org/10.1016/j.jmarsys.2003.08.002

Soro, G., Metongo, B. S., Soro, N., Ahoussi, E. K., Kouame, F. K., Zade, S. G. P., \& Soro, T. (2009). Heavy Metals (Cu; Cr; Mn; Zn) in the Surface Sediments of an African Tropical Lagoon: Case of the Ebrié Lagoon (Ivory Coast) (p. 20). LSTEE, UFHB, CRO.

Tastet, J. P., \& Guiral, D. (1994). Geology and Sedimentology. In Durand, J.-R., Dufour, P., Guiral, D. and Zabi, S., Eds., Environment and Aquatic Resources of Côte d'Ivoire. Volume II, Lagoon Environments (pp. 35-58). Paris: ORSTOM.

Touré, M., N’Guessan, A. Y., \& Konan, E. K. (2018). Geochemical Study of the Surface Sediments of a Lagoon Bay and Its Impact on the Environment: Case of the Bay of Abouabou (Ebrié Lagoon; Côte d'Ivoire). International Journal of Biological and Chemical Sciences, 12, 2371-2380. https://doi.org/10.4314/ijbcs.v12i5.35

Traore, A., Ake-Assi, Y., Ahoussi Kouassi, E., \& Soro, N. (2015). Evaluation of the Concentration of Trace Elements $(\mathrm{Pb}, \mathrm{Cu}, \mathrm{Zn}, \mathrm{Fe}, \mathrm{Cd}$ and $\mathrm{Hg}$ ) in Shrimps (Macrobrachium vollenhovenii) from the Aghien and Potou Lagoons (South-Eastern Côte d'Ivoire). Larhyss Journal, 24, 129-142.

Traore, A., Soro, G., Ahoussi, K. E., Bamba, B. S., Soro, N., \& Biemi, J. (2014). Level of Heavy Metal Contamination in the Sediments of a Tropical Lagoon: The Aghien Lagoon (South-Eastern Côte d'Ivoire). Africa Science, 10, 73-88.

Traore, A., Soro, G., Kouadio, E. K., Bamba, B. S., Oga, M. S., Soro, N., \& Biemi, J. (2012). Assessment of the Physical, Chemical and Bacteriological Parameters of the Waters of a Tropical Lagoon during the Low-Flow Period: The Aghien Lagoon (Côte d'Ivoire). International Journal of Biological and Chemical Sciences, 6, 7048-7058. https://doi.org/10.4314/ijbcs.v6i6.40

Wango, T. E., Toure, M., \& N'Guessan, Y. M. (2015). Bathymetry of a Lagoon Bay and Its Impact on the Distribution of Heavy Metals: Case of the Bay of Abouabou in the Ebrié Lagoon, Côte d'Ivoire. Africa Science, 11, 37-44.

Wedepohl, K. H. (1995). The Composition of Continental Crust. Geochimica et Cosmochimica Acta, 59, 1217-1232. https://doi.org/10.1016/0016-7037(95)00038-2 